\title{
MULCHING WITH TERRACE STRENGTHEN ON SURFACE RUNOFF, EROSION, AND SEDIMENT ENRICHMENT RATIO
}

Trinugraheni', Jaka Suyana ${ }^{2}$, Sumarno ${ }^{3}$

1) Undergraduated Students of Agrotechnology, Agriculture Faculty, University of Sebelas Maret Surakarta

2) Lecturer of Agrotechnology, Agriculture Faculty, University of Sebelas Maret Surakarta

3) Lecturer of Agrotechnology, Agriculture Faculty, University of Sebelas Maret Surakarta

Contact Author: trinugraheni23@yahoo.com

\section{ABSTRACT}

Land degradation causes increase erosion on agricultural land. Andisol soil contains more fractions sand making aggregate easily dispersed. Soil loss due to erosion can lead to nutrients loss needed by plants. Corn stem mulching to reduce erosion and runoff.Corn stem mulch can be combined with terrace strengthen to decrease surface runoff and erosion. The study used randomized block design with 4 treatments and repeated 3 times as a block so that there are 12 experimental unit. Category of group iscabbage, red lentils and white lentils. The results showed that corn stem mulch 12 ton $^{-1}$ ha with kalanjana + annona able to reduce $4,5 \%$ of surface runoff, erosion $15,5 \%$.Corn stem mulch 4 ton $^{-1}$ ha with Vetiverazizanioides+Annona squamosa as terrace strengthen withSER (Sediment Enrichment Ratio) has a (C-organic $=0,94 ; \mathrm{N}$-total = 1,04; P-total $=2,21 ; \mathrm{P}$-available $=1,40 ; \mathrm{K}$-total of 0,87 ; K-available 0,73 ) and suppresses loss nutrients in the Andisol soil.

Keywords: Surface runoff, erosion, corn stem mulch, terrace strengthen

AGROTECHNOLOGY RESEARCH JOURNAL

Trinugraheni, Suyana J, Sumarno. 2016. Mulching with terrace strengthen on surface runoff, erosion, and sediment enrichment ratio. Agrotech Res J 1(1):28-32.

\section{INTRODUCTION}

Degradation due to surface erosion is very intense and widespread in Indonesia (Rusdi 2013). Erosion causes loss of fertile top soil to plant growth and the reduced ability of soil to absorb and hold water runoff (Arsyad 2010). According to Sutrisno (2012) the level of erosion in the watershed Keduang is 44 ton / ha / year. Erosion causes loss of nutrients $\mathrm{N}(105.4 \mathrm{~kg} / \mathrm{ha}), \mathrm{P}$ $(712.5 \mathrm{~g} / \mathrm{ha}), \mathrm{K}(1710 \mathrm{~g} / \mathrm{ha})$ and organic material $(2.210 \mathrm{~kg} / \mathrm{ha})$ that can make up the loss 100 billion / year.

Andisol widely used for vegetable crops. Andisol has texture that dominated by the sand fraction and had a bit of clay fractions which cause soil andisol easily pass the water and has a low aggregate so easily eroded. It would lead to depletion of nutrient availability and soil organic matter if the land management does not pay attention to the conservation techniques (Juarti 2016).

The use of vegetative conservation concoction can be an alternative in handling the problem of erosion. Corn stem mulch on the cultivation of cabbage can reduce the erosion rate of up to $91.46 \%-94.49 \%$ on slopes $25-45^{\circ}$. Resolving a loss of C-organic between $88.84 \%-89.36 \%$, and increased production between $13.33 \%-21.69 \%$ (Rahayu 2014). According to research Are (2011) states that the use of mulch strip $10 \mathrm{~m}+4$ ton / ha vetiver can be a good choice for soil and water conservation rather than simply using the strip or mulch. The use of mulch strip $10 \mathrm{~m}+4$ ton $^{-1}$ ha vetiver significantly decrease runoff by $63.7 \%$, soil loss between $77 \%-84 \%$, the collection of nutrients in the sediment, reduce the level of erosion of $33.3 \%-77.7 \%$, and improving soil structure.
Based on the description above soil conservation research is needed to determine the effect of the combination of mulching corn stem with a terrace strengthen strip on surface runoff, erosion and sediment enrichment ratio.

\section{METHOD}

The research was conducted in the village of Setren, District Slogohimo, Wonogiri, with altitude of 1100 with Andosol soil types. Fieldwork was conducted from April to July 2015. The study was conducted at the Laboratory of Chemistry and Soil Fertility Laboratory, Faculty of Agriculture, UNS Surakarta. This research was using a randomized block design with 4 treatments and repeated 3 times as a group (block) so that there are 12 experimental unit. Breakdown by category plants, red lentils, cabbage and lentils white. The treatment on the use as follows:

MS1: Mulching corn stem 0 ton/ha without terrace strengthe

MS2: Mulching corn stem 4 ton/ ha with Vetiverazizanioides+Annona squamosa as terrace strengthen

MS3: Mulching corn stem 8 ton/ha with Coix lacryma-jobi L.+Annona squamosa as terrace strengthen

MS4: $\quad$ Mulching corn stem 12 ton/ha with Panicum muticum+Annona squamosa as terrace strengthen

Erosion and surface runoff were analyzed by analysis of variance (ANOVA) if significantly different followed by a DMRT (Duncan's Multiple Range Test) level of $5 \%$. Nutrient loss and sediment enrichment ratioanalyzed by Descriptive.

${ }^{*}$ Fak. Pertanian UNS Surakarta

JI. Ir. Sutami 36 A Surakarta

Mulching with Terrace Strengthen on Surface Runoff, Erosion, and Sediment Enrichment Ratio (Trinugraheni, 


\section{RESULT AND DISCUSSION}

\section{Surface runoff}

Based on DMRT (Duncan's Multiple Range Test) level of $5 \%$ use of treatments and plant species has a significant effect on surface runoff (Table 1). The result showed that treatment significantly different MS1 with MS4. Surface runoff that occurs in treatment MS1 (Mulching corn stem 0 ton/ha without terrace strengthen) is treated with the greatest results is 712.02 m3 / ha, whereas treatment MS4 (Mulching corn stem 12 ton/ha with Panicum muticum+Annona squamosa as terrace strengthen) is treated with the smallest result is $677.53 \mathrm{~m} 3$ / ha. Mulching reduce surface runoff, soil loss and improve infiltration onsloping ground (Adekalu 2007). Plant red lentils significantly affected crop of white lentils. Soil transported in plants red lentils is $680.97 \mathrm{~m} 3$ / ha, whereas cabbage and white lentils is $696.23 \mathrm{~m} 3$ / ha, $705.38 \mathrm{~m} 3$ / ha. Growth and morphology different effect on surface runoff. Effect on the type of plant used plant canopy to shade the ground. The canopy at the plant will make the water flow in the leaves, branches and stems of the plant so that it can inhibit the rate of surface runoff and allow water to enter the soil and is absorbed by roots.

Table 1 Effect treatment and kind of plants to surface runoff on April-July 2015

\begin{tabular}{|c|c|c|c|c|c|c|c|}
\hline \multirow{2}{*}{ Treatment } & \multirow{2}{*}{$\begin{array}{r}\text { Rain fall } \\
(\mathrm{mm})\end{array}$} & \multicolumn{3}{|c|}{ Kind of plant $\left(\mathrm{m}^{3} / \mathrm{ha}\right)$} & \multirow{2}{*}{$\begin{array}{r}\text { Average } \\
\left(\mathrm{m}^{3} / \mathrm{ha}\right)\end{array}$} & \multirow{2}{*}{$\begin{array}{r}\text { \% Surface } \\
\text { runoff to } \\
\text { rainfall }\end{array}$} & \multirow{2}{*}{$\begin{array}{r}\text { Decreased } \\
\text { surface } \\
\text { runoff }(\%)\end{array}$} \\
\hline & & Red lentils & Cabbage & White lentils & & & \\
\hline MS1 & 262,00 & 700,42 & 713,07 & 722,58 & $712,02 a$ & 27,18 & \\
\hline MS2 & 262,00 & 681,04 & 698,44 & 704,40 & $694,63 a$ b & 26,51 & 2,44 \\
\hline MS3 & 262,00 & 678,43 & 696,66 & 702,66 & $692,58 a b$ & 26,43 & 2,73 \\
\hline MS4 & 262,00 & 663,98 & 676,76 & 691,88 & $677,54 b$ & 25,86 & 4,84 \\
\hline Rata-rata & & 680,97 & 696,23 & 705,38 & & & \\
\hline
\end{tabular}

Description: the number of the same font followed on the same line or colum showed no real difference in test DMRT (Duncan's Multiple Range Test) standard of 5\%.

The collision of raindrops directly on the soil surface causes splash (splash erosion) (Monde 2010). Rain water drop directly on the ground will damage the soil aggregates and increase soil erodibility. Rain water to the soil surface, it will go into the ground as water infiltration and partly by gravity flow to a lower place as surface flow (Kadir 2013).

Soil which is covered by corn stem mulch will reduce the strength of rainwater on destruction of soil aggregates as submitted by Wahjunie (2012) that mulching can reduce the process of destruction of soil aggregates due to the energy of water droplets from rain drop to the ground. Stocked mulch on the soil surface, inhibiting grain rain that falls resulting collision energy to zero. It makes the water that goes into the ground only in the form of streams of fine, dispersion of soil aggregates can be reduced so that the closing process of soil pores by fine particles at ground level can be reduced. The use of strip plants which is planted on the porch bench and mulch wereto pressing water and allow the water to infiltrate the soil surface so that the flow can drop significantly.

\section{Erosion}

Soil erosion and nutrient loss caused by the high volume of runoff can reduce crop yields and impact damage to the other place (Cogle 2002). To reduce erosion and the loss of nutrients, use hedgerow system is one variation of soil conservation is recommended for mountainous areas in the tropics. This system combines the concept of plantinglegumes or fodder grass with annual crops (Pansak 2008).

Based on the results of erosion that occurred (Table 2), the addition of Mulching corn stem 12 ton $^{-1}$ ha with Panicummuticum+Annonasquamosa as terrace strengthen has a smallest of value erosion 10.79 ton ${ }^{1}$ ha. Litter corn is a material which used as a mulch to protect from erosion, suppress weeds when growth (Pansak 2008). The use of plants as a real block has a different effect on erosion. Plant red lentils plant significantly different with white lentils. Plants red lentils has erosion of 9,06 ton $^{-1}$ ha, whereas in plants the white lentils of $13,68 \operatorname{ton}^{-1}$ ha. Increase use of land cover affect the existing erosion on the land (Borin 2005).

Variations vegetation land cover will give a different effect for each plant has a different morphology. The closure of the plant canopy and extensive anchor different roots in every kind of plant will affect the erosion that occurs on that land.

According to Rosliani et al. (2010) stated red lentils signifies the rapid growth so that the ability of the roots and leaf canopy prevents rain water break down the aggregates soil than cabbage. It is also reinforced by the opinions Marhendi (2014) which states red lentils plant legume is a plant that is widely used as a cover crop. Plants red lentils can improve land productivity through improved physical soil, reduce erosion, increase organic matter, increase the soil's ability to absorb and retain rainwater damaging impact soil aggregation. White lentils plant is a plant which growth is the slowest compared with red lentils and cabbage because of inappropriate height not. 
Table 2 Effect treatment and kind of plants to erosion on April-July 2015

\begin{tabular}{lrrrrrr}
\hline \multirow{2}{*}{ treatment } & \multirow{2}{*}{ rainfall $(\mathrm{mm})$} & \multicolumn{3}{c}{ Blok $\left(\right.$ ton $\left.^{-1} \mathrm{ha}\right)$} & $\begin{array}{r}\text { average } \\
\text { (ton/ha) }\end{array}$ & $\begin{array}{r}\text { Decrease } \\
\text { erosion }(\%)\end{array}$ \\
\cline { 3 - 6 } & & Red lentils & cabbage & WhiteLentils & $12,77 \mathrm{a}$ & \\
MS1 & 262 & 10,52 & 12,55 & 15,25 & $11,08 \mathrm{a}$ & 13,25 \\
MS2 & 262 & 7,83 & 11,73 & 13,69 & 1,25 & 14,42 \\
MS3 & 262 & 8,34 & 11,47 & 12,99 & $10,93 \mathrm{a}$ & 15,52 \\
MS4 & 262 & 9,58 & 9,23 & 13,56 & $10,79 \mathrm{a}$ & \\
Rata-rata & & $9,06 \mathrm{a}$ & $11,24 \mathrm{a} \mathrm{b}$ & $13,68 \mathrm{~b}$ & & \\
\hline
\end{tabular}

Description: the number of the same font followed on the same line or colum showed no real difference in test DMRT (Duncan's Multiple Range Test) standard of 5\%.

\section{Nutrient on sediment}

Andisol soil has high permeability and high rain water infiltration capability, but with regard to the extent of the impact of fragmentation on aggregate due to rain andsmaller transport (Zehetner 2006). Andisol soil conditions become an attention to erosion, according Neris (2012) that dominate from erodible soil erosion. Andisol soil has a high organic carbon, crumb structure and a low bulk density. Low bulk density will dominate transport in soil reservoirs (Rodriguez 2002). In research's field, soil Andisol have particles that are dominated by sand $(41,67 \%)$, dust $(39,61 \%)$ and clay $(23,66 \%)$. The high ability of soil aggregates break down rain will cause soil particles are dispersed to be easily carried by the flow (Neris 2002). Powered by Cogle statement (2002) that the soil erosion and loss of nutrients due to the high volume of runoff can reduce crop yields and impact on other areas of damage due to sediment.

According to Asdak (2010) that soil was transported in soil erosion is the topsoil which contains a lot of nutrients required by plants. Soil borne by erosion will be collected in the sump erosion. The content of nutrients in the sediment include: organic materials including high between 2,9 to 3,3\%, total $\mathrm{N}$ content of the soil is very high between 0,75 to $0,79 \%$, P-total between 0,03 to $0,05 \%$. P-provided between 6,68 $10,78 \mathrm{ppm}$ include low to moderate due to soil fixation Andisol has a problem in P (Hardjowigeno 2003). K- total between 0,11 to $0.15 \%$, and the $\mathrm{K}$-available between 52,31 to $69,43 \mathrm{mg}^{-1} 100 \mathrm{~g}$ is high to very high. Some of nutrient contents of sediment have value larger than the initial soil. It is called sediment enrichment ratio (SER) (Arsyad 2010).

Nutrient content is based on the type of plant has different levels. It is determined from the results of soil sediment erosion on the land. Types of plants which influence through state roots and canopy of plants. Plants take necessarynutrients for their growth needs.

Sources major supplier of carbon into the soil are: (a) the plant canopy trees and crops that go as litter and the rest of the harvest; (B) the roots of plants, through the roots die, the ends of the roots, root exudation and respiration of roots; (C) biota. Litter and dead roots that go into the ground will soon overhauled by heterotrophic organisms, and then entered the pool of soil organic matter. While the loss of $C$ in the soil can be via (a) soil respiration, (b) plant respiration, (c) transported harvest, (d) is used by the biota, (e) erosion (Hairirah 2010). Organic mulch will return organic matter and plant nutrients to the soil and improve the physical, chemical and biological soil that has been decomposed, and can increase production yield. Organic carbon would be significant if more application of organic mulch. C-organic content of the soil would be even less if it does not use organic mulch (Bhardwaj 2013).

Table 3 Initial soil nutrient content and sedimentation on treatment

\begin{tabular}{|c|c|c|c|c|c|c|c|c|c|c|c|c|}
\hline \multirow[b]{2}{*}{ Treatment } & \multicolumn{6}{|c|}{ Soil } & \multicolumn{6}{|c|}{ sedimentation } \\
\hline & $\begin{array}{l}\text { C-organic } \\
(\%)\end{array}$ & $\begin{array}{l}\text { N-total } \\
(\%)\end{array}$ & $\begin{array}{l}\text { P-total } \\
(\%)\end{array}$ & $\begin{array}{l}\text { P- } \\
\text { available } \\
(\mathrm{ppm})\end{array}$ & $\begin{array}{l}\text { K- } \\
\text { total } \\
(\%)\end{array}$ & $\begin{array}{l}\text { K } \\
\text { availabl } \\
\text { e (mg } \\
\left.{ }^{1} 100 \mathrm{~g}\right)\end{array}$ & $\begin{array}{l}\text { C- } \\
\text { organik } \\
(\%)\end{array}$ & $\begin{array}{l}\mathrm{N} \text {-total } \\
(\%)\end{array}$ & $\begin{array}{l}\text { P-total } \\
(\%)\end{array}$ & $\begin{array}{l}\text { P- } \\
\text { availabl } \\
\text { e (ppm) }\end{array}$ & $\begin{array}{l}\text { K-total } \\
(\%)\end{array}$ & $\begin{array}{l}\mathrm{K} \\
\text { availabl } \\
\mathrm{e}\left(\mathrm{mg}^{-}\right. \\
\left.{ }^{1} 00 \mathrm{~g}\right)\end{array}$ \\
\hline MS1 & 2,94 & 0,67 & 0,03 & 4,88 & 0,11 & 89,27 & 3,01 & 0,79 & 0,03 & 7,08 & 0,11 & 169,43 \\
\hline MS2 & 3,12 & 0,73 & 0,02 & 4,768 & 0,12 & 72,067 & 2,93 & 0,76 & 0,04 & 6,69 & 0,11 & 52,31 \\
\hline MS3 & 2,94 & 0,71 & 0,02 & 5,404 & 0,09 & 76,87 & 3,37 & 0,79 & 0,05 & 6,78 & 0,12 & 59,93 \\
\hline MS4 & 2,95 & 0,69 & 0,03 & 6,382 & 0,10 & 61,30 & 3,21 & 0,77 & 0,06 & 10,79 & 0,15 & 68,24 \\
\hline
\end{tabular}

Source: laboratorium result

\section{Sediment enrichment ratio}

Erosion and surface runoff will cause soil loss on the erosion area and cause sedimentation in other areas (Arsyad 2006). Nutrient content of total N, P2O5, K2O, and $\mathrm{C}$-organic transported through runoff and erosion are higher than the residue that is left in the ground indicated by Sediment Enrichment Ratio (SER)> 1 (Haridjaja 2012).
Ratio enrichment in c-organic sediment is between 0,94 to 1,15 (Table 4). This value is lower than the research of the faculty of agriculture and veterinary science, University of Nairobi, Kenya which found enrichment value for C-organic sediment with an average of 1,22 to 1,09 to 1,32 range it may be caused by the presence of soil type and sampling in gutter that causes the $\mathrm{C}$-organic less than c-organic on sediments (Arsyad 2006). 
Sediment enrichment ratio in the $\mathrm{N}$-total greatly affected by the closure of mulch is given. The addition of mulch closure will increase the value of SER up to a certain value, but will decrease the value of SER on a certain amount of mulch. The addition of mulch after the decline in the value of SERSER will increase again. Based on research conducted by Sinukaban Up (2007) states that the value SER N-total at the close of $0 \%$ has an SER score of 6.4 , on the closure of $30 \%$ rose to 8,4 ; the addition of mulch closure to $60 \%$ will decrease to 7,8 SER and the closure of $90 \%$ will increase the SER back to $9.0 \%$. Mulching and fertilizing chemicals that can increase the number of total- $\mathrm{N}$ in the soil. Increased $\mathrm{N}$-total proved that the organic material is a major source of soil $\mathrm{N}$ after the organic materials decompose. This increase occurred in the treatment of organic mulch (Raihana 2006).

Physical organic mulch to protect from temperature fluctuations, stabilize soil moisture, help in the preservation of the land, and, reduce evaporation. Agronomically, organic mulch helps the possibility of the survival of plants, reduce the loss of transpiration of plants, and increase productivity. Effects on soil is to reduce the loss of nutrients through runoff, increase infiltration of rainwater into the soil, thereby reducing surface runoff reduces soil compaction so that the stem easily explore the nutrients from the soil (Ossom and Matsenjwa, 2007).
SER on p-total ranged from 1,20 to $2,28 \%$ (Table 4). Increased levels of $\mathrm{P}$-total in the sediment causing sediment enrichment ratio. The ratio due to nutrient enrichment of sediment and organic material is generally bound to the clay fraction, if the content of the clay fraction in the sediment erosion results higher than the initial soil (soil erosion) then the place to experience sedimentation would experience nutrient enrichment (Arsyad 2010).

Table 4 shows that the content of $\mathrm{P}$-available generally increased. The $p$-available is in most low sediment is in treatment MS3 SER 1,25. Treatment (MS1) has SER 1,45. Treatment (MS2) SER 1,40. Treatment (MS4) has the highest SER score of 1,69 . SER on p-available was 1,45 and ranged from 1,25 to $1,69 \%$.

The addition of mulch on the surface resulting in runoff, reduced to the transport capacity of runoff decreases. Coarse sediment deposition behind mulch suffered, but fine sediments such as clay and colloidal still carried along the surface flow this adding mulch resulted in more selective surface flow measuring sediment and colloidal clay. The fine sized sediment more actively bind c-organic and nutrient, then the increase mulch eventually result in erosion containing concentrations of c-organic and nutrient higher Although there decline in the value of erosion and surface runoff (Sinukaban 2007).

Table 4 Sediment enrichment ratio on treatment

\begin{tabular}{lrrrrrr}
\hline \multirow{2}{*}{ treatment } & \multicolumn{7}{c}{ Sediment enrichment ratio } \\
\cline { 2 - 7 } & C-Organik & N-Total & P-Total & P-Available & K-Total & K-Available \\
\hline MS1 & 1,02 & 1,18 & 1,21 & 1,45 & 1,03 & 0,78 \\
MS2 & 0,4 & 1,04 & 2,20 & 1,40 & 0,87 & 0,73 \\
MS3 & 115 & 1,11 & 2,53 & 1,25 & 1,35 & 0,78 \\
MS4 & 1,09 & 1,11 & 2,28 & 1,69 & 1,49 & 1,11 \\
\hline
\end{tabular}

Source:laboratorium result

\section{Surface runoff, erosion, and nutrient loss}

Table 5 relationship between increasing doses and types of corn stalks mulch strip terrace amplifier will reduce runoff and erosion. Surface runoff that occurs between 677,54 to $711,02 \mathrm{m3}^{-1}$ ha, erosion between $10,79-12,77$. Loss of nutrients nitrogen between 82,87 $101,39 \mathrm{Kg}^{-1} \mathrm{Ha}$. Loss of nutrients phospor between $4,34-6,15 \mathrm{Kg}^{-1} \mathrm{Ha}$. Loss of nutrients potassium between $11,74-15,97 \mathrm{Kg}^{-1} \mathrm{ha}$ and for organic $\mathrm{C}$ between. 324,97 $\left.384,25 \mathrm{Kg}^{-1} \mathrm{Ha}\right)$.

Treatment mulch with terrace reinforcing strip against surface runoff and erosion increasing doses greater mulch and different types of strips will reduce runoff there. Sedimentation is rich in nutrient content. Extra doses of mulch corn stalks to the type of reinforcement strips of different terraces will increase nutrient levels in the sediment. Erosion is smaller does not make nutrient content becomes smaller because of the selectivity of the process of erosion. The selectivity of erosion causing sediment with coarse particles such as sand gets stuck behind a mulch while sediments with fine particles such as clay will carry over into the tank. Clay is a lot of particles that bind nutrients (Sinukanan 2007).

Table 5 Correlation surface runoff, erosion and nutrient loss on treatment

\begin{tabular}{|c|c|c|c|c|c|c|}
\hline treatment & $\begin{array}{l}\text { Surface runoff } \\
\left(\mathrm{m}^{3-1} \mathrm{ha}\right)\end{array}$ & $\begin{array}{l}\text { Erosion } \\
\text { (ton }{ }^{-1} \text { ha) }\end{array}$ & $\mathrm{N}\left(\mathrm{Kg}^{-1} \mathrm{Ha}\right)$ & $\mathrm{P}\left(\mathrm{Kg}^{-1} \mathrm{Ha}\right)$ & $\mathrm{K}\left(\mathrm{Kg}^{-1} \mathrm{Ha}\right)$ & C-Organik $\left(\mathrm{Kg}^{-1} \mathrm{Ha}\right)$ \\
\hline MS1 & 711,02 & 12.77 & 101.394 & 4.3418 & 13.7916 & 384.249 \\
\hline MS2 & 694,62 & 11.08 & 83.9864 & 4.8752 & 11.7448 & 324.976 \\
\hline MS3 & 692,58 & 10.93 & 85.8005 & 5.2464 & 13.5532 & 368.778 \\
\hline MS4 & 677,54 & 10.79 & 82.8672 & 6.1503 & 15.9692 & 345.927 \\
\hline
\end{tabular}

Source: laboratorium result 


\section{CONSLUSIONS and RECOMENDATIONS}

\section{Conslusions}

Based on the research mulch with terrace strengthen strip to the surface runoff, erosion and sediman enrichment ratio has been carried out, can be summed up is as follows:

1. On MS4 (Mulching corn stem 12 ton $^{-1}$ ha with Panicum muticum + Annona squamosa as Strengthen terrace) can lower that $4.84 \%$ and $15,52 \%$ are likely to have on the SER Organic nutrient $\mathrm{C}=1,09 ; \mathrm{N}=1,11 ; \mathrm{P}$-total $=2,28, \mathrm{P}$ available $=1,69 ;$ K-total 1,50; K-available 1,11.

2. Ratio enrichment of sediments is influenced by factors seletivitas erosion. Treatment is most effective in suppressing the loss of nutrients and ratio enrichment of the sediment is treated MS2( Mulching corn stem 14 ton $^{-1}$ ha with Vetiverazizanoides + Annona squamosa as Strengthen terrace) hasSER (C-organic $=0.941, \mathrm{~N}=$ 1,035; P-total $=2,211 ; \mathrm{P}$-Available $=1,403 ; \mathrm{K}$-total 0,871; K-provided 0,73).

\section{Recomendations}

Suggestions generated by this research for future research are as follows

1. The use of conservation with a combination of mulch cornstem 4 ton / ha with a strengthen strip vetiver grass terrace and srikaya used by farmers to reduce the impact of runoff, erosion, and sediment enrichment ratio.

2. Search concoction in accordance with a dose of mulch cornstem have the most significant effect on nutrient loss and sediment enrichment ratio.

\section{REFERENCE}

Adekalu KO, Olorunfemi LA, Osunbita JA. 2007. Grass mulching effect on infiltration, surface runoff, and soil loss of three agricultural soils in Nigeria. J Bioresource Techn. 98:912-917.

Are KS, Babalola O, Oke AO, Oluwatosin GA, Adelana $\mathrm{AO}$ et al. 2011. Conservation strategies for effective management of eroded landform: soil structural quality, nutrient enrichment ratio, and runoff water quality. J Soil Sci. 176(5):252-263.

Arsyad S. 2010. Konservasi tanah dan air. Bogor(ID): IPB Press

Bhardwaj RL. 2013. Effect of mulching on crop production under rainfed condition-A Review. J Agri Review. 34(3):188-197.

Borin M, Vianello M, Morari F, Zanin G. 2005. Effectiveness of buffer strips in removing pollutants in runoff from a cultivated field in north-east italy. J Agric Eco And Environ. 105:101-114.

Cogle AL, Rao KPC, Yule DF, Smith GD, George PJ et al. 2002. Soil management for andisols in the semiarid tropics: erosion, enrichment ratios and runoff. J Soil Use and Management.18:10-17.

Hardjowigeno S. 2003. Klasifikasi tanah dan pedogenesis. Jakarta(ID): Akademika Presindo

Hardjowigeno S. 2007. Klasifikasi tanah dan pedogenesis. Jakarta(ID): Akademika Presindo
Haridjaja O, Yahya S, Hafid N. 2012. Nisbah pengkayaan sedimen dan pencucian hara melalui aliran permukaan dan erosi tanah pada pertanaman kakao . (Abstrak). Thesis. Institut Pertanian Bogor

Juarti. 2016. Analisis indeks kualitas tanah andisol pada berbagai penggunaan lahan di desa Sumber Brantas Kota Batu. J pend geo. 21(2): 58-71.

Kadir I, Pomalingo N, Nurmi. 2013. Efektivitas mulsa vertikal dalam mengurangi kehilangan hara $P$ (fosfor) melalui aliran permukaan danerosi. Skripsi. Fakultas IImu-IImu Pertanian. Universitas Negeri Gorontalo

Marhendi T. 2014. Teknologi pengendalian erosi lahan. J Techno. 15(1):50 - 64

Neris J, Jimenez C, Fuentes J, Morillas G, Tejedor M. 2012. Vegetation and land-use effect on soli properties and water infiltration odandisol in tenerife (canary island, spain). J Catena. 98:55-62.

Pansak W, Hilger TH, Dercon G, Kongkaew T, Candish G. 2008. Changes in the relationship between soil erosion and $n$ loss pathways after establishing soil conservation systems in uplands of Northeast Thailand. J Agric, Eco \& Environ. 128:167-176.

Rahayu E. 2014. Pengaruh teknik konservasi secara vegetative terhadap erosi tanah pada budidaya kentang (solanum tuberosum) dan kubis (brassica oleracea) di desa kasimpar, das serayu hulu. Tesis. Fakultas Pertanian. Universitas Gadjah Mada. Yogyakarta.

Raihana Y dan William E. 2006. Pemberian mulsa terhadap tujuh varietas kacang hijau dan keharaan tanah di Lahan Lebak Tengahan. Bul Agron. 34(3):148-152.

Rodríguez R A, Guerra JA, Gorrín SP, Arbelo CD, Mora JL. 2002. Aggregates stability and water erosion in andosols of the canary islands. J Land Degrad\& Develop. 13(6):515-523.

Rosliani R, Sumarni N, Sulastrini I. 2010.Pengaruh cara pengolahan tanah dan tanaman kacang-kacangan sebagai tanaman penutup tanah terhadap kesuburan tanah dan hasil kubis di dataran tinggi. $J$ Hort. 20(1):36-44

Rusdi, Alibasyah M R, Karim A. 2013. Evaluasi degradasi lahan diakibatkan erosi pada areal pertanian di kecamatan lembah seulawah kabupaten aceh besar. J Konserv Sumber Daya Lahan. 1(1):24-39

Sutrisno J, Bunasir S, Asep S, dan Santun RPS 2012. Valuasi ekonomi erosi lahan pertanian di sub das keduang kabupaten wonigiri. SEPA 8 (2): 157-161

Wahjunie ED, Sinukaban N, Damanik BSD. 2012. Perbaikan kulaitas fisik tanah menggunakan mulsa jerami padi dan pengaruhnya terhadap prduksi kacang tanah. J Tanah Lingk. 14 (1):7-13.

Winarno J, Ariyanto DP, Hartati S, Rosariastuti R. 2008. Kajian bahaya erosi pada lahan kering di Sub DAS Samin kabupaten karanganyar. J Iltan dan Agroklim. 5(2):101-106.

Zehetner F, Miler WP. 2006. Erodibilityandrunoffinfiltration characteristics of vulcanic ash soils along an altitudinal climosequence in the ecuadorianandes. J Catena. 65:201-213. 